\title{
Original DocumentsRemarks on the Contract for Building Catterick Bridge
}

\section{E.J. Wilson}

To cite this article: E.J. Wilson (1850) Original DocumentsRemarks on the Contract for Building Catterick Bridge, Archaeological Journal, 7:1, 292-295, DOI: 10.1080/00665983.1850.10850792

To link to this article: http://dx.doi.org/10.1080/00665983.1850.10850792

曲 Published online: 06 Dec 2014.

Submit your article to this journal

Q View related articles $₫$ 


\section{Brigimal 煟ocuments.}

\section{REMARKS ON THE CONTRACT FOR BUILDING CATTERICK BRIDGE.}

THE following observations on the contract for building a bridge at Catterick, in the North Riding of Yorkshire, dated in 1421-2, have been made, in order to assist towards the explanation of certain obscure passages and obsolete terms occurring in that curious document, which have not been clearly explained in the former part of the Journal.

It would have been more satisfactory if reference could be made to plans and sections of the bridge, such as accompanied the printed copy of a contract for building Catterick church, dated in $1412 .^{2}$ The value of original documents of this nature, in reviving and elucidating the terms of art used by our old builders, is too obvious to every student of antient architecture to need any recommendation of them to his careful perusal. A comparison of Catterick bridge with that over the river Tees at Barnard Castle, which probably had been erected not long before this at Catterick, and to which reference is made in this contract, as to a model which was to be copied with certain modifications, would also, no doubt, have illustrated the terms which now seem so obscure; but, unluckily, the present bridge at Barnard Castle is not the building spoken of in the Catterick contract, -for that bridge was ruined in the insurrection headed by the Earls of Northumberland and Westmorland, in 1569, when Barnard Castle was held by Sir George Bowes, of Streatlam, for eleven days, against the insurgents, to whom he was at last obliged to give it up. The bridge now standing at Barnard Castle was built in 1596, and has only two arches. Catterick bridge was to have two pillars, two landstathes, and three arches. So far, the description is clear, and needs no comment. It was also to have five courses of egeoves, of the same thickness, and like the egeoves of Barnard Castle bridge. The term here used raises a difficult question. I cannot accept the explanations suggested in page 60 , and can only imagine that it refers to the ribs which are commonly found in the arches of the bridges of the middle ages; of which there were to be here five in each of the three arches. But this conjecture is not borne out by the form of the arches of Catterick bridge, which are plain, and have no ribs; nor can we now appeal to the bridge at Barnard Castle for elucidution of this part of the contract. Here it seems necessary to observe, that the English word ogee is only used to designate a certain form of moulding, composed of two curved lines,-one convex, the other concave. ${ }^{3}$ And this word appears to have only come into use amongst our artists since the revival of classic architecture. But the term ogive in the French language bears a very different meaning; and we find the most intelligent writers on the Con-

1 See pp. 56-62, in this volume.

Published in 4 to., 1834, Weale, London; with thirteen plates of Catterick Church, drawn by Anthony Salvin, F.S.A., Architect. Edited by the Rev. James Raine. It is a curious and valuable work, although the architecture of the church is mean and homely.

3 See Professor Willis' Architectural Nomenclature, published by the Cambridge Antiquarian Society, 1844. The learned 
tinent speaking commonly of "l'architecture Romane, ou a plein-cintre," and its transition, "a l'architecture Gothique ou a ogives." Again, we find " des arches aigües, ogives," with many similar expressions, showing that ogive is a general term in French for a pointed arch. Moreover, the frequent use of the plural number in the application of this term leads me to infer that the ogive, properly, denotes a curve less than the fourth part of a circle, - a pointed arch being composed of two such curves; whilst the arche a plein-cintre contains a semi-circle. ${ }^{4}$ We must bear in mind that the greater number of our old terms of architecture were borrowed from the French language; and so, I believe, was this term in the contract for Catterick bridge. It is true that the want of ribs in the arches of this bridge goes directly against the application of the term to that member ; and I can only account for this apparent contradiction by supposing that either the arches have been rebuilt in a different form, as was the case with the bridge at Barnard Castle, or that an alteration was made in the progress of the work,-and the ribs intended by the contract were not formed,-perhaps in order to lessen the charge of construction. The word Brandreth, or Branderathe, is another term requiring explanation. The two pillars and the two landstathes of the bridge were to have their several brandereths. These, whatever might be their form or use, were to be framed of timber, and were to be furnished by the gentlemen who made the contract with the masons, and whom, for the sake of distinction, I shall call the trustees. These parties were to find all the timber, or tre-werke, as it is called, that was required for the construction of the bridge. These brandereths were evidently considered of great importance to the stability of the masons' work, as the times at which they were to be laid down by the trustees, with the help of the masons, are distinctly specified. The first brandereth, for one landstathe, was to be laid before the Invention (or feast of the finding) of the Holy Cross, May 3rd, 1422. The other, for the opposite landstathe, by the Nativity of St. John Baptist, on the 24th of June. The brandereth for one pillar was to be laid by the 3rd of May, in the following year, and that for the other pillar by the 24 th of June.

The use of coffer-dams in building bridges was unknown, I believe, tu the builders of bridges in the middle ages; and the usual practice was to turn the current of water aside, by some means, until the lower portions of masonry were built. In this case, I suppose, the trustees, who covenanted to keep off the water and prevent its annoying the masons, diverted the course of the Swale, a shallow stream in summer time, by temporary weirs; so that the landstathes could be built in the first summer, and the pillars in the second. The brandereths, I think, were frames of timber, laid flat, below the bottom courses of stone, in order to strengthen the foundations, and give them an equal pressure on the soil. I have not, indeed, seen the term so employed in any architectural document; but I have heard such a frame, made to support a stack of corn, and set upon large stones to raise it from the ground, in a farm-yard, called a brandereth; and that would

author has enlarged upon the brief explanation of this term given in the Glossary to Pugin's Specimens of Gothic Architecture [4to., third edition, 1825 , p. 16], but the term deserves a more thorough investigation.

4 M. de Caumont, in an essay on the ecclesiastical architecture of Normandy in the middle ages, printed in the Memoires de la Soc. des Antiquaires de la Normandic, 8vo., 1825 , made very frequent use of the term ogive, applying it to the pointed arch; and subsequent French writers have continued to use it in the same sense. 
agree very well with the supposed application of the term to such frames used in the foundations of the bridge. ${ }^{5}$

The "Alluryng oure watir," I understand as describing the parapetwall on each side of the bridge. This usage of the term agrees exactly with the contract for building Catterick church; where the same word occurs several times in describing the parapets to the roofs of the choir and aisles of the church.

The word Alur, which, like all other old terms, is variously spelt, properly signified an alley, or walking-place, upon the roof or upper part of a building. ${ }^{6}$ But it was also applied to the parapet, or battlement, in front ; and was used here to describe the side-walls which guarded the passage over the bridge.

A luge ${ }^{7}$ or lodge, for the use of the masons, was to be erected by the trustees, at the bridge. It was to be constructed of wood, to contain four rooms, to be covered, and made reasonably close; and was also to have two hen-forkes. These appurtenances to the lodge may have been, as has been suggested (see p. 61, ante), lean-to's, or pent-houses, attached to the sides of the lodge. Possibly they may have been two yards, one on each side of the lodge, inclosed with planks, to keep off intruders from interrupting the masons at their work ; for all the old artificers were jealous of strangers, and careful to keep their modes of working as private as possible. But if, as I suppose, the lodge served for the masons' dwelling-house, as well as the place for their work, these hen-forkes may have been two garrets, constructed in the roof of the lodge, over the four rooms which it was to contain. Such garrets were commonly called cock-lofts in old accounts, and the word is still used sometimes in country-districts. At Oxford and Cambridge cock-lofts were made in the roofs of several of the old colleges, in the reigns of Elizabeth and James I., to accommodate the undergraduates, who in earlier times had been content to rest on trucklebeds, in the same chambers with the fellows; as we are told by Anthony a Wood and other historians. The cock-loft derived its name from such a loft being commonly the roosting-place for poultry in country houses ; henroost, or hen-house, are terms still in use; and the same etymology would apply to the hen-forke. ${ }^{8}$ If this conjecture be right, the syelles mentioned in the contract might be intended to describe the ceilings, or floors of boards, over the four rooms in the lodge; and the hen-forkes would serve for sleeping-places for the apprentices and workmen, whilst the mastermasons reposed in some of the rooms below. ${ }^{9}$

5 This usage of the word agrees also with the explanation of it given in Lord Monson's MS. of 1483 . [Sce the reference in p. 61 of the Journal.] That MS. was consulted in the compilation of the Glossary to Specimens of Goth. Archit., and is referred to under the designation of MS. M. The publication of this curious Dictionary, with annotations by an able editor, would be very useful and interesting.

6 "Upe the alurs of the castles the laydes thanne stode

And bylulde thys noble game, and wyche knygts were god."

Robert of Gloucester's Chronicle, vol. i., 192. Edit. Hearne
These ladies stood upon the roofs of the castles, and looked over the battlements to behold the exercises of the knights, who were tilting and jousting below for their amusement.

7 The words lodgings, to lodge, lodgers, \&c., are commonly pronounced ludgings, to ludge, ludgers, \&c., by uneducated people in some parts of Lincolnshire and Yorkshire.

8 In Scotland and the north of England, poultry in general are called hens, without attending to the distinction of sexes.

9 Sir William Lawson suggests, in reference to the term hen-forke, that it may imply an open-ridged roof, as distinguished from ceiled rooms, the timbers bearing a resemblance to 
In the volume of " Memorials of the Rebellion in 1569," published in 1840 , 8vo. at page 387, Sir George Bowes, who had commanded the Queen's forces, states, in a petition to her majesty, that " They [the rebels] have utterly defaced my principall house, pullynge downe and carrienge awaye the glasse and iron of the wyndowes, and all syelinge and doors, and some part of the coverynge, being leade." He also says, in a passage printed at page 101, from one of Sir George's letters, “ I am utterly spoylled-my housses fully defaced, by pulling away off the dores, wyndowes, irons off the wyndowes, sylying, and all my brewe vessels and other vessels, and chymnees apperteyninge my kytchyn." Another notice occurs at p. 405 of this plundering, which chiefly occurred at Streatlam Castle, Durham, then Sir George Bowes' principal residence. The syelinge, or sylynge, here said to have been torn out of the rooms, undoubtedly refers to the wainscot panels with which the walls were lined. In the mason's lodge, this term might mean a lining of boards, either above or at the sides of the rooms. The word ceiling, which in modern usage refers only to the upper surface of a room, was formerly applied also to the sides. Instances of this usage occur in Gage's History of Hengrave, Suffolk, 4to. 1822, pp. 42,43 ; where the learned author has mistaken the nature of a contract for wainscotting the rooms of Hengrave Hall, A. D. 1537.

The seentrees were evidently the centres, as we are accustomed to call the frames used for supporting arches until the stones have all been fixed in their proper places; and perhaps this old term may not be erroneously formed, though it does not agree with our scientific derivation of the modern word.

The words abown or aboon, for above ; aboonsaid for abovesaid; fro or fra, instead of from; and several other old-fashioned words in the contract are still in common use in the northern counties. Fromity or frumety, mentioned in note 7, p. 57 , is a better word than furmity; which is only one of the many instances in which our good old English speech has been corrupted by modern affectation. Frumety derives its name from the wheat (frumentum), which is the basis of this favourite dish; one of the " country messes" we have inherited from our ancestors.

E. J. WILSON.

* * We were not aware, when this curious contract was communicated by the kindness of Sir William Lawson, that it had been previously printed (in 1829) in that inexhaustible store-house of antiquarian information, the Gentleman's Magazine (Vol. xcix., part i., p. 394). A transcript, we have ascertained, had been given by the late Sir Henry Lawson to Mr. Clarkson, the historian of Richmond, who communicated it to Mr. Urban, under the signature of " Richmondiensis." Being there given without any illustrative comment, and from a transcript very deficient in accuracy, there can be no cause to consider its republication superfluous. It is singular that no subsequent writer on ancient architectural terms, appears to have noticed so curious a document.

the "merrythought, a forked bone in the body of a fowl."-Ash's Dict. As children with narrow chests are familiarly called chicken-breasted, such a forked roofing may have been termed hen-forked, as contrasted with sheds, having a lean-to roof, not forked, and called in Northern dialect, To-falls, or Tee-falls._Ev. 